\title{
Integration of moral values during L2 sentence processing.
}

\author{
Alice Foucart ${ }^{1}$, Eva Moreno ${ }^{2}$, Clara D. Martin ${ }^{3,4}$ \& Albert Costa ${ }^{1,5}$
}

1- $\quad$ University Pompeu Fabra, carrer Roc Boronat, 138, 08018 Barcelona, Spain

2- Instituto Pluridisciplinar, Universidad Complutense de Madrid, Paseo Juan XXIII, 1, 28040, Madrid, Spain

3- BCBL. Basque Center on Cognition, Brain and Language, Paseo Mikeletegi, 69, 20009 Donostia-San Sebastian, Spain

4- $\quad$ IKERBASQUE, Basque Foundation for Science, Maria Diaz de Haro 3, 48013 Bilbao, Spain ICREA, Institució Catalana de Recerca i Estudis Avançats, Barcelona, Spain

Corresponding author:

Dr. Alice Foucart

Universitat Pompeu Fabra

Department of Technology (room 55116)

Roc Boronat, 138, 08018

Barcelona

Spain

Phone: +34 935422362

Email: alfoucart@gmail.com

\section{Highlights}

- Valuation is integrated online during L2 sentence comprehension.

- $\quad$ Valuation does not interfere with semantic processing in L2 sentence processing.

- $\quad$ Value-inconsistent statements provoke N400 and LPP components 


\begin{abstract}
This study reports an event-related potential (ERP) experiment examining whether valuation (i.e., one's own values) is integrated incrementally and whether it affects L2 speakers' online interpretation of the sentence. We presented Spanish native speakers and French-Spanish mid-proficiency late L2 speakers with visual sentences containing value-consistent and value-inconsistent statements (e.g., 'Nowadays, paedophilia should be prohibited/tolerated across the world.'). Participants' brain activity was recorded as they were reading the sentences and indicating whether they agreed with the statements or not. Behaviourally, the two groups revealed identical valuation. The ERP analyses showed both a semantic (N400) and an affect-related response (LPP) to value-inconsistent statements in the native group, but only an LPP in the non-native group. These results suggest that valuation is integrated online (presence of LPP) during L2 sentence comprehension but that it does not interfere with semantic processing (absence of N400).
\end{abstract}

Keywords: Second language sentence comprehension, semantic processing, moral values, ERPs 


\section{Introduction}

Sentence processing does not only involve gaining access to the meaning of words being read or heard; other sources of information, such as pragmatic information, are also retrieved during language comprehension. For example, when reading “Divorce is unacceptable”, the interpretation of the adjective 'unacceptable' will vary depending on one's own opinion about divorce. Native speakers seem to retrieve pragmatic information rapidly and incrementally during first language (L1) online comprehension. For instance, they can assess the veracity of a sentence thanks to quick access to their world knowledge stored in long term memory (e.g., 'Mozart composed classical/jazz music'; Hagoort, Hald, Bastiaansen, \& Petersson, 2004; Martin, Garcia, Breton, Thierry, \& Costa, 2014). They can interpret the intelligibility of a sentence according to the speaker's indexical properties (e.g., the speaker's voice, like in 'Every night I drink a glass of wine', said by an adult/child; Van Berkum, van den Brink, Tesink, Kos, \& Hagoort, 2008). And similarly, they can interpret a sentence according to their own value system (e.g., 'Divorce is unacceptable', presented to a Christian/non-Christian listener; Van Berkum, Holleman, Nieuwland, Otten, \& Murre, 2009). Fast and incremental integration of information favours quick interpretation of the message conveyed. Much less is known, however, on whether these sources of information are used and retrieved during second language (L2) comprehension. The present study aims at exploring how and when valuation processes come into play when processing sentences in an L2. Achieving a better understanding of whether and how these processes take place will help us unveil difficulties often associated with sentence processing in $\mathrm{L} 2$.

To our knowledge, the only evidence about online retrieval of pragmatic information in L2 sentence processing is limited to two studies that revealed some 
differences between L1 and L2 sentence processing (Foucart et al., 2015; Martin, Garcia, Breton, Thierry, \& Costa, under review; see below for a more detailed description). In the current article, we aim at completing this picture, by looking at how valuation processes function in an L2 context. Note that valuation processes, unlike world knowledge and indexical properties that involve information independent of the comprehender (i.e., facts of the world), are comprehender-dependent since they involve personal affect. Given that affect-based stimuli or statements usually provoke a less intense reaction in second language (L2) than in first language (L1) (Caldwell-Harris \& Ayçiçeği-Dinn, 2009; Dewaele, 2004; Opitz \& Degner, 2012; Pavlenko, 2005), it is not immediately obvious that valuation be integrated incrementally and that it affect L2 speakers' online interpretation of a sentence. The present paper investigates this question by looking at the online valuation of a statement in relation to one's moral values.

Many event-related potential (ERP) studies investigating L2 sentence processing have focused on semantic processing, and the general conclusion is that L2 speakers can reach native-like performance. Indeed, since Ardal and colleagues' seminal study, the N400 effect found in native speakers in response to semantic violations has been consistently observed in L2 speakers as well, however, very often delayed (Ardal, Donald, Meuter, Muldrew, \& Luce, 1990; Hahne \& Friederici, 2001; Hahne, 2001; Kutas \& Kluender, 1994; Meuter, Donald, \& Ardal, 1987; Weber-Fox \& Neville, 1996; for reviews, see Frenck-Mestre, Sneed German, \& Foucart, 2014; Moreno, RodriguezFornells, \& Laine, 2008). The N400 component peaks around 400 ms and has a centroparietal distribution. It is considered to reflect the semantic integration of a word within a sentential context (Kutas \& Hillyard, 1980); its presence during L2 sentence 
comprehension suggests that semantic processing is similar in L1 and L2. However, it is still unclear why its time-course often shows a temporal delay.

Recently, it has been proposed that the difference of time-course may reveal difficulties in integrating pragmatic information online. Costa and colleagues investigated whether L2 speakers take world knowledge (Martin et al., under review) and the speaker's identity (Foucart et al., 2015) into account when incrementally processing speech and whether this affects their online interpretation of a sentence. They presented native speakers and L2 speakers with sentences with either semantic violations (e.g., Mozart composed orange music) or pragmatic inconsistencies (e.g., 'Mozart composed jazz music'; 'Every night I drink a glass of wine', said by a child). Both groups showed similar responses to semantic violations (an N400 distributed over the whole scalp; but see Martin et al., 2014; Martin et al., under review, for a discussion on earlier effects). In regards to pragmatic inconsistencies, world knowledge violations produced an N400 effect in native and non-native speakers (the effect was distributed over the whole scalp and was smaller than that in response to semantic violations). Inconsistencies in indexical properties generated a positivity over centro-parietal sites for both groups, although earlier for L2 speakers. These results suggest that, depending on the source of pragmatic information, online integration occurs at a different timecourse in L1 and L2 sentence comprehension. The authors proposed that this difference may stem from L2 speakers' sensitivity to pragmatic information and/or their ability to efficiently make use of the information provided by the sentence context to generate expectations in relation to pragmatic information.

This conclusion is in line with linguistic studies showing that L2 speakers are more sensitive to pragmatic information than native speakers and tend to rely more on pragmatic cues when facing linguistic integration difficulties (Felser, Sato, \& 
Bertenshaw, 2009; Roberts \& Felser, 2011; Roberts, Gullberg, \& Indefrey, 2008). This assumption is rooted in the observation that when a linguistic situation is complex, any cues (e.g., linguistic, visual) that can render comprehension easier is likely to be used. If one of these cues is not available or distorted, processing becomes more difficult (Hattori, 1987). In relation to L2 comprehension (which is usually more difficult than L1 comprehension), it has been put forward that late bilinguals may indeed give more weight to some cues than to others to compensate for their difficulty to process complex structures (Clahsen \& Felser, 2006a, 2006b; Papadopoulou \& Clahsen, 2003; Ullman, 2005). Hence, it is possible that during sentence processing late bilinguals rely on cues they master well (such as pragmatic cues which are language-independent), and consequently, be more sensitive to these cues.

L2 speakers, however, may not be as sensitive to valuation; indeed, as mentioned above, valuation is comprehender-dependent since it involves affect. Studies have shown that the emotional reaction to affect-based stimuli or statements is usually reduced in L2 (Caldwell-Harris \& Ayçiçeği-Dinn, 2009; Opitz \& Degner, 2012; Pavlenko, 2005). For example, swear words provoke lesser physiological arousal in L2 than L1 (Dewaele, 2004) and emotional words or short phrases in L2 provoke reduced skin conductance amplitudes (Harris, Ayçiçeği, \& Gleason, 2003; Harris, 2004). Hence, if L2 speakers are less sensitive to this type of pragmatic information, they may not integrate valuation online or the time-course may vary compared to L1. So far, most studies investigating sentence processing have used an 'error paradigm' in which semantic violations are manipulated (for review, see Frenck-Mestre et al., 2014; Moreno et al., 2008); here, we used correct sentences in which 'violations' are provoked by a conflict with one's moral values. Manipulating sentences that require evaluating the meaning in relation to one's values allowed verifying whether valuation affects L2 
speakers' online interpretation of the message. To this end, we adapted Van Berkum et al.'s (2009) study in which statements were either congruent or incongruent with one’s own values.

In that study, Van Berkum and colleagues (Van Berkum et al., 2009) examined how rapidly one's values come into play when processing a statement and whether values can influence the linguistic-semantic analysis of that statement. Using an attitude-survey on societal issues, they tested two groups of participants with opposing values (i.e., members of a Christian party vs. non-Christian party) and recorded their brain activity as they were completing the survey. Participants were presented with sentences that either matched or clashed with their own values (e.g., I think euthanasia is an unacceptable/acceptable course of action.) and had to indicate whether they agreed with the statement or not. The ERP analyses from the onset of the critical word revealed a small N400 effect (375-425 ms) and a late positivity (LPP; 500-650 ms). They also observed an early positivity (200-250 ms) that they speculated was the onset of a long lasting positivity that was temporarily interrupted by the N400 effect, as observed in previous studies (Cacioppo, Crites, Berntson, \& Coles, 1993; Crites, Cacioppo, Gardner, \& Berntson, 1995). Interestingly, the N400 component had the same distribution over centro-parietal sites than the effect provoked by semantic violations (Kutas \& Hillyard, 1980). The LPP, on the other hand, was observed over the whole scalp, when this component usually has a centro-parietal maximum in response to emotional stimuli. The same pattern was observed in the two groups but for opposite statements depending on their own values. The authors interpreted the N400 effect observed as an indication of difficulty of early sense making, reflecting the difficulty of integrating a word within the context when it conflicts with one's value. They related the late positivity they observed to the late positive potential (LPP) usually elicited in 
response to the emotional intensity of a stimulus (pictures or words) (Cuthbert, Schupp, Bradley, Birbaumer, \& Lang, 2000; Hajcak, MacNamara, \& Olvet, 2010; for a review, see Citron, 2012).

In sum, from Van Berkum et al's (2009) study, it seems that processing a statement that goes against one's values provokes an affect-related response (reflected by an LPP) and difficulty of semantic integration (reflected by an N400). The authors suggested that valuation may have a non-controlled, automatic influence on language processing. Importantly for our purpose, these results demonstrate that when comprehending a sentence, native speakers do not only process words within a context but they also evaluate the meaning of the sentence in relation to their own moral values. Hence, semantic processing and valuation are processed online during L1 sentence comprehension. In the present paper, we investigated whether it is also the case during L2 sentence comprehension.

\section{The present study}

Following Van Berkum et al.’s (2009) study, we presented written sentences in which the critical word either matches or conflicts with one's values. In contrast with Van Berkum, however, we did not base our sentences on the beliefs of a specific group (e.g., Christian political party) but we relied on 'common values' that, we assumed, the majority of people living in Europe would concord with (see Table 1 for examples and Appendix for full list of materials). To ensure that participants agreed with these values, they were asked to rate their (dis-)agreement with each statement on a 5-point scale.

We tested a group of L1 Spanish speakers and a group of late L2 French-Spanish speakers. Native speakers were tested as a control group, and also to replicate the effects observed in Van Berkum et al.’s study and extend them to another language, Spanish. 
According to their results, we expected a small N400 effect and an LPP effect around $500 \mathrm{~ms}$ in the L1 group, potentially preceded by an early positivity around $200 \mathrm{~ms}$. This pattern of effects would imply, as previously put forward by Van Berkum et al., that valuation has a non-controlled, automatic influence on L1 semantic processing.

Regarding the L2 group, we selected two Romance languages, French and Spanish, as their lexical and syntactic properties largely overlap, and, as previously demonstrated, cross-language similarities aids language processing (Foucart, Martin, Moreno, \& Costa, 2014; Tokowicz \& MacWhinney, 2005; van Hell \& Tokowicz, 2010). Assuming that we replicated Van Berkum's results in the control group, we should observe ERP components reflecting semantic processing and valuation; a similar pattern, i.e., an N400 and an LPP in the L2 group would suggest that both semantic information and valuation are integrated online, in the same way as in L1. If the N400 component was absent but the LPP was present, it would suggest that L2 speakers can evaluate a statement in relation to their own moral values during online sentence comprehension but that such valuation does not interfere with earlier semantic processes. Finally, if no effect were observed at all, it would suggest that L2 speakers are not sensitive to value-disagreement statements online.

\subsection{Method}

\subsubsection{Participants}

Twenty-four Spanish native speakers (19 females, 22.6 years, range 19-32) and 24 French-Spanish mid-proficiency late L2 speakers (15 females, 22.5 years, range 2032; mean age similar for the two groups, $t(24)=0.11, p=.91)$ took part in the experiment and received monetary compensation for their participation. Native speakers were students at the University Complutense de Madrid (Spain), and L2 speakers were 
studying at university level in Barcelona, Spain (mean immersion time: 18.6 months, 672 months). French-Spanish L2 speakers had learned Spanish at school (mean age of acquisition: 13.7 years, 8-22 years). In a language background questionnaire, they provided a self-assessment of their level of Spanish (from 1: very poor to 7: excellent) for written comprehension (5.4, SD: 0.9), written production (5, SD: 1.1), oral production (5.2, SD: 1) and oral comprehension (5.6, SD: 1.1). In addition, to take part in the experiment, they were required to pass a Spanish language test (B2 level of the Common European Framework; mean score: 15.8 out of 20, SD: 3). Prior to the experiment, all participants received oral and written information about the procedure and signed a consent form. Participants also took part in a study investigating word anticipation in L2 (Foucart et al.’s, 2014).

\subsubsection{Material and design}

We composed 80 sentences related to what we considered common moral values. Each sentence contained an adjective. Two versions of each sentence were created by manipulating the critical adjective so that the statement was either consistent (Moral condition) or not (Immoral condition) with common moral values. Critical adjectives were balanced in frequency (Moral condition: 22.4 per million, SD: 33.3; Immoral condition: 19.8 , SD: 35.2; $t(80)=0.48, p=.63$; BuscaPalabras, Davis \& Perea, 2005) and length (Moral condition: 9.1 letters, SD: 1.8; Immoral condition: 9 letters, SD: $2.2 ; t(80)=0.49, p=.63)$ across conditions. In each condition, adjectives with positive and negative connotation were mixed to ensure that any effect was due to the valence of the adjective in relation to the context and not to the emotional valence of the adjective itself (e.g., ‘Pegar a los niños es negativo para su educación.’; Beating kids is

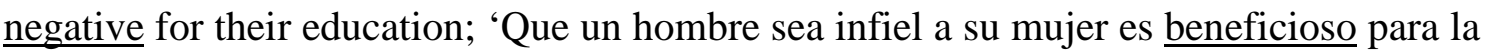


pareja.'; A man being unfaithful to his wife is beneficial for a couple). Half of the sentences included an impersonal statement (e.g., 'Beating kids...) and the other half a personal statement (e.g. 'I believe...', 'according to me...'), placed either at the end or beginning of the sentence. This design was done to vary the nature of the sentences in the experiment but was not analysed.

For both conditions, we also included the same 80 adjectives in control sentences in which they appeared at a position prior to the topic they were related to (e.g., 'Es positivo/negativo para su educación pegar a los niños.’; It is positive/negative for their education to beat kids). This was to control that any effect obtained was not due to the processing of the adjective itself, but to the way it modified the statement. Overall, control sentences were slightly shorter than experimental sentences (control sentences: 8.2 words; SD: 2.30; experimental sentences: 10.9; SD: 2.2; $t(80)=-9.15, p$ $<.001$ ). To avoid wrap-up effects, the critical adjective was never placed in the final position of the sentence. Examples of each condition are provided in Table 1 and a full list in the Appendix.

Two lists of 160 sentences were created with 40 sentences in the Moral condition, 40 in the Immoral condition, 40 in Control Moral condition and 40 in Control Immoral condition. The adjective was seen in the Moral condition in one list and in the Immoral condition in the other. The two lists were balanced in terms of frequency (List A: 19.7 per million, SD: 25.4; List B: 22.5, SD: 41.3; $t(80)=-0.53, p=.60$ ) and length (List A: 8.89 letters, SD: 2; List B: 9.2, SD: 2; $t(80)=-2.27, p=.21$ ) of the adjective. Each sentence appeared only once in each list, in one version or the other (Moral or Immoral) of the experimental and control conditions. 
Table 1. Examples of sentences presented in each condition.

Conditions Sentences

Moral

En nuestra época, la pedofilia debería ser prohibida en todo el mundo.

Immoral En nuestra época, la pedofilia debería ser tolerada en todo el mundo.

Nowadays, paedophilia should be prohibited/tolerated across the world.

Control moral Debería ser tolerada la pedofilia.

Control Immoral Debería ser prohibida la pedofilia.

Should be tolerated/prohibited paedophilia. (literal translation)

\subsubsection{Procedure}

Participants were presented with one of the two lists using the presentation software E-Prime 2.0 (Psychology Software Tools, 2012). All sentences were presented in one block. For both lists 4 semi-randomised versions were created, with the only constraint that the experimental version was always presented before the control version in order to avoid participants to anticipate the critical adjective when given the topic context. Each trial started with a 1000 ms fixation cross and sentences were displayed on the screen word by word (350 ms word duration and $350 \mathrm{~ms}$ inter-stimulus interval). After each sentence, participants were asked to express their agreement or disagreement with the statement on a scale from 1 (I totally disagree) to 5 (I totally agree). Participant's answer triggered the following trial. Participants were told they could blink or take a short break whenever the scale was displayed on the screen; for this 
reason, response times were not recorded. The experiment was preceded by 5 sentences of practice and lasted about 20 min (excluding cap set-up).

\subsubsection{EEG recording and data analysis}

Electrophysiological data were recorded from 31 tin electrodes attached to an elastic cap (Electrocap International), placed according to the standard International 1020 locations (Jasper, 1958) and referenced on the nose. EEG activity was recorded with a band-pass filter between $0.1 \mathrm{~Hz}$ and $200 \mathrm{~Hz}$, continuously digitised at a sampling rate of $500 \mathrm{~Hz}$, and re-filtered offline at $30 \mathrm{~Hz}$ low pass. The electrode impedance was set below $5 \mathrm{k} \Omega$. Epochs ranged from $-100 \mathrm{~ms}$ to $1000 \mathrm{~ms}$ after the onset of the critical adjective. Artifacts were automatically rejected for each participant (differences in values $200 \mu \mathrm{v}$ in 200 ms intervals, and amplitudes of $+/-100 \mu \mathrm{v}$ ), resulting in $8.7 \%$ and $3 \%$ of rejection across conditions for the native speaker and L2 speaker groups, respectively. Baseline correction was performed in reference to pre-stimulus activity (100; $0 \mathrm{~ms}$ ) and individual averages were digitally re-referenced to the average of the mastoid electrodes.

The ERP data were quantified by calculating the mean voltage amplitudes. Following Van Berkum et al.’s study, we were interested in two main effects: the N400 and the LPP. ERP components respective to these effects were defined based on the grand averages and corresponded roughly to the time-windows used by Van Berkum et al., i.e., 380-500 ms, and 675-800 ms time-windows, respectively. In addition, analyses were performed in an earlier time-window to explore the presence of an early positivity as in Van Berkum's study but no significant differences emerged. We conducted analyses of variance (ANOVAs) for each time-window. At midline, a three-way ANOVA was conducted with Group (native vs. non-native speakers) as a between 
participant factor and repeated measures for Morality (Moral vs. Immoral statement) and Electrode (Fz, Cz, Pz, Oz). At lateral sites, four-way ANOVAs were performed separately on frontal, centro-parietal and occipital sites with Group as a between participant factor and repeated measures on Morality, Hemisphere (left/right) and Electrode, with four levels of electrode. The levels of electrodes were defined as follows: frontal sites (left: F7, F3, FC5, FC1, right: F8, F4, FC6, FC2), centro-parietal sites (left: T3, C3, CP5, CP1, right: T4, C4, CP6, CP2) and occipital sites (left: T5, P3, PO1, O1, right; T6, P4, PO2, O2). We decided to perform separate ANOVAs to allow observing potential distributional effects ${ }^{1}$. When an interaction was significant, post-hoc (Bonferroni test) were conducted. The Greenhouse-Geisser correction (Greenhouse \& Geisser, 1959) was applied to all repeated measures with greater than one degree of freedom; in this case, the corrected $p$-value is reported. Analyses were conducted on the totality of the sentences ${ }^{2}$. The grand averages for the native group and the L2 group are presented in Figures 1 and 2, and Figures 3 and 4, for the experimental conditions and the control conditions, respectively.

\subsection{Results}

\subsubsection{Behavioural answers}

Behavioural answers are reported in Table 2. Overall, participants (L1 and L2 speakers) agreed with the 'moral statements' $86 \%$ of the time (sum of 'I totally agree' and 'I agree') and disagreed with the 'immoral statements' $90 \%$ of the time (sum of 'I totally disagree' and 'I disagree'), which suggests that the sentences indeed addressed common moral values. Analyses were conducted on expected responses (i.e., 'I totally agree' and 'I agree’ for Moral and Control Moral; 'I totally disagree' and 'I disagree' for Immoral and Control Immoral. No differences were found between native and non- 
native speakers for neither of the conditions (Moral, $t(46)=-0.56, p=.57$; Immoral, $t(46)=0.11, p=.92 ;$ Control Moral, $t(46)=-0.12, p=.90)$; Control Immoral, $(t(46)=$ $0.6, p=.95)$.

Table 2. Behavioural answers in percentage and standard deviation in parentheses.

\begin{tabular}{|c|c|c|c|c|c|c|}
\hline \multirow[t]{2}{*}{ Conditions } & Groups & I totally & I disagree & I do not & I agree & I totally \\
\hline & & disagree & & know & & agree \\
\hline \multirow[t]{2}{*}{ Moral } & L1 & $6.6(9)$ & $2.2(2.9)$ & $5.7(4.8)$ & $10.6(12.9)$ & 74.9 (13.9) \\
\hline & L2 & $4.1(3.4)$ & $3.2(2.7)$ & $5.6(4.7)$ & $10.9(7.7)$ & 76.1 (12.5) \\
\hline \multirow[t]{2}{*}{ Immoral } & L1 & $81.2(15)$ & $8.8(9.2)$ & $5.1(4.8)$ & $1.7(2.4)$ & $3.1(9.1)$ \\
\hline & L2 & 81.5 (12.3) & $8.0(7.4)$ & $5.1(4.9)$ & $2.4(3.9)$ & $3.0(3.4)$ \\
\hline Control & L1 & $6.7(5.4)$ & $2.3(2.3)$ & $5.8(4.7)$ & $9.8(14.7)$ & 75.4 (14.8) \\
\hline Moral & L2 & $6.2(4.8)$ & $2.9(2.7)$ & $4.5(4.6)$ & $11.1(10.2)$ & 74.4 (12.6) \\
\hline Control & L1 & $81.3(14.2)$ & 8.5 (10.7) & 4.5 (5.9) & $1.9(3.7)$ & $3.9(4.2)$ \\
\hline Immoral & L2 & $82.6(11.8)$ & $6.9(6.1)$ & $4.5(3.4)$ & $2.0(3.9)$ & $3.9(4.5)$ \\
\hline
\end{tabular}

\subsubsection{ERPs analyses}

N400 (380-500 ms)

The ANOVAs (summary of results reported in Table 3) revealed a significant main effect of Morality at all but frontal sites. The factor Group did not reach significance. An interaction Morality x Group was observed, and post-hoc analyses revealed it was due to the factor Morality being significant in the native speakers group (midline: $p$ 
$<.02$; frontal sites: $p=.27$; centro-parietal sites: $p<.03$; occipital sites: $p<.02$ ) but not in the L2 speakers group ( $p=1$ at all sites). In addition, an interaction Morality $\mathrm{x}$ Electrode was found at centro-parietal sites only, revealing that the effect was slightly larger at central electrodes than at temporal electrodes. The interaction Morality $\mathrm{x}$ Group x Electrode was not significant. The factor Morality never interacted with Hemisphere. Thus, immoral statements provoked a larger negativity than moral statements in the native group; while this was not true in the L2 speakers group in which no difference was observed between the two types of statement. The N400 was observed at (centro-)posterior sites, which is the classic distribution of this component. In the Control condition, the main effect of Morality was not significant (midline: $F(1$, $46)=0.22, p=.64)$; frontal sites: $F(1,46)=0.72, p=.40)$; centro-parietal sites: $F(1$, $46)=0.32, p=.57)$; occipital sites: $F(1,46)=1.40, p=.24)$. Morality did not interact with Group (midline: $F(1,46)=0.01, p=.94$ ); frontal sites: $F(1,46)=0.28, p=.60$ ); centro-parietal sites: $F(1,46)=0.09, p=.77)$; occipital sites: $F(1,46)=0.16, p=.69$ ).

\section{LPP (675-800 ms)}

The ANOVA (summary of results reported in Table 3) performed in this time-window showed a significant main effect of Morality at all sites but frontal sites. The factor Group did not reach significance. The factor Morality did not interact with Group. No interaction with Electrode or Hemisphere was found. The interaction Morality x Group x Electrode did not reach significance either. These results indicate that in both groups immoral statements provoked a larger positivity than moral statements, and that this positivity was distributed similarly in the two groups (i.e., at (centro-)posterior sites).

In the Control condition, the main effect of Morality was not significant (midline: $F(1$, $46)=1.70, p=.20)$; frontal sites: $F(1,46)=0.54, p=.46)$; centro-parietal sites: $F(1$, 
$46)=1.32, p=.26)$; occipital sites: $F(1,46)=0.98, p=.33)$. Morality did not interact with Group (midline: $F(1,46)=0.17, p=.68$ ); frontal sites: $F(1,46)=0.01, p=.90$ ); centro-parietal sites: $F(1,46)=0.01, p=.94)$; occipital sites: $F(1,46)=0.42, p=.52)$.

Table 3. Summary of the statistical results of the ERPs in the time-windows 380-500 ms and 675-800 ms time-windows for the experimental conditions. Reported values are rounded up. Abbreviations used for the effects and interactions: $G=$ Group, M = Morality, E= Electrode. The factor Hemisphere never interacted with Morality and is, therefore, not reported here for a matter of space. Significant $p$-values are in bold.

\begin{tabular}{|c|c|c|c|c|c|c|c|}
\hline & \multicolumn{4}{|c|}{ Time-window 380-500 ms } & \multicolumn{3}{|c|}{ Time-window 675-800 ms } \\
\hline & df & $F$ & $p$ & $\eta^{2}$ & $F$ & $p$ & $\eta^{2}$ \\
\hline \multicolumn{8}{|c|}{ Midline sites } \\
\hline G & 1,46 & 0.03 & .85 & .001 & .10 & .74 & .002 \\
\hline M & 1,46 & 4.08 & .05 & .08 & 5.3 & .03 & .10 \\
\hline MxG & 1,46 & 5.35 & .02 & .025 & 3.45 & .07 & .07 \\
\hline $\mathrm{MxE}$ & 3,138 & 0.75 & .52 & .016 & 0.84 & .47 & .18 \\
\hline MxGxE & 3,138 & 0.46 & .71 & .01 & 0.19 & .90 & .001 \\
\hline \multicolumn{8}{|c|}{$\underline{\text { Frontal sites }}$} \\
\hline G & 1,46 & 0.49 & .48 & .01 & 1.95 & .17 & .04 \\
\hline M & 1,46 & 1.94 & .17 & .04 & 2.44 & .12 & .05 \\
\hline $\mathrm{MxG}$ & 1,46 & 2.29 & .13 & .04 & 1.39 & .24 & .03 \\
\hline $\mathrm{MxE}$ & 3,138 & 0.82 & .48 & .02 & 2.55 & .06 & .52 \\
\hline MxGxE & 3,138 & 0.57 & .63 & .012 & 0.94 & .42 & .02 \\
\hline \multicolumn{8}{|c|}{ Centro-parietal sites } \\
\hline G & 1,46 & 0.12 & .72 & .002 & .43 & .51 & .01 \\
\hline M & 1,46 & 4.01 & .05 & .08 & 4.73 & .03 & .09 \\
\hline $\mathrm{MxG}$ & 1,46 & 4.75 & .03 & .09 & 2.10 & .15 & .04 \\
\hline $\mathrm{MxE}$ & 3, 138 & 3.73 & .01 & .75 & 6.32 & .001 & .12 \\
\hline MxGxE & 3, 138 & 2.31 & .08 & .05 & 1.32 & .27 & .03 \\
\hline \multicolumn{8}{|c|}{ Occipital sites } \\
\hline G & 1,46 & 0.98 & .32 & .02 & 0.77 & .38 & .16 \\
\hline
\end{tabular}




\begin{tabular}{cccccccc}
$\mathrm{M}$ & 1,46 & 4.81 & .03 & .09 & 5.26 & .03 & .10 \\
$\mathrm{MxG}$ & 1,46 & 5.08 & .03 & .09 & 2.75 & .10 & .06 \\
$\mathrm{MxE}$ & 3,138 & 1.16 & .32 & .02 & 1.79 & .15 & .04 \\
$\mathrm{MxGxE}$ & 3,138 & 2.66 & .06 & .06 & 1.45 & .23 & .03 \\
\hline
\end{tabular}

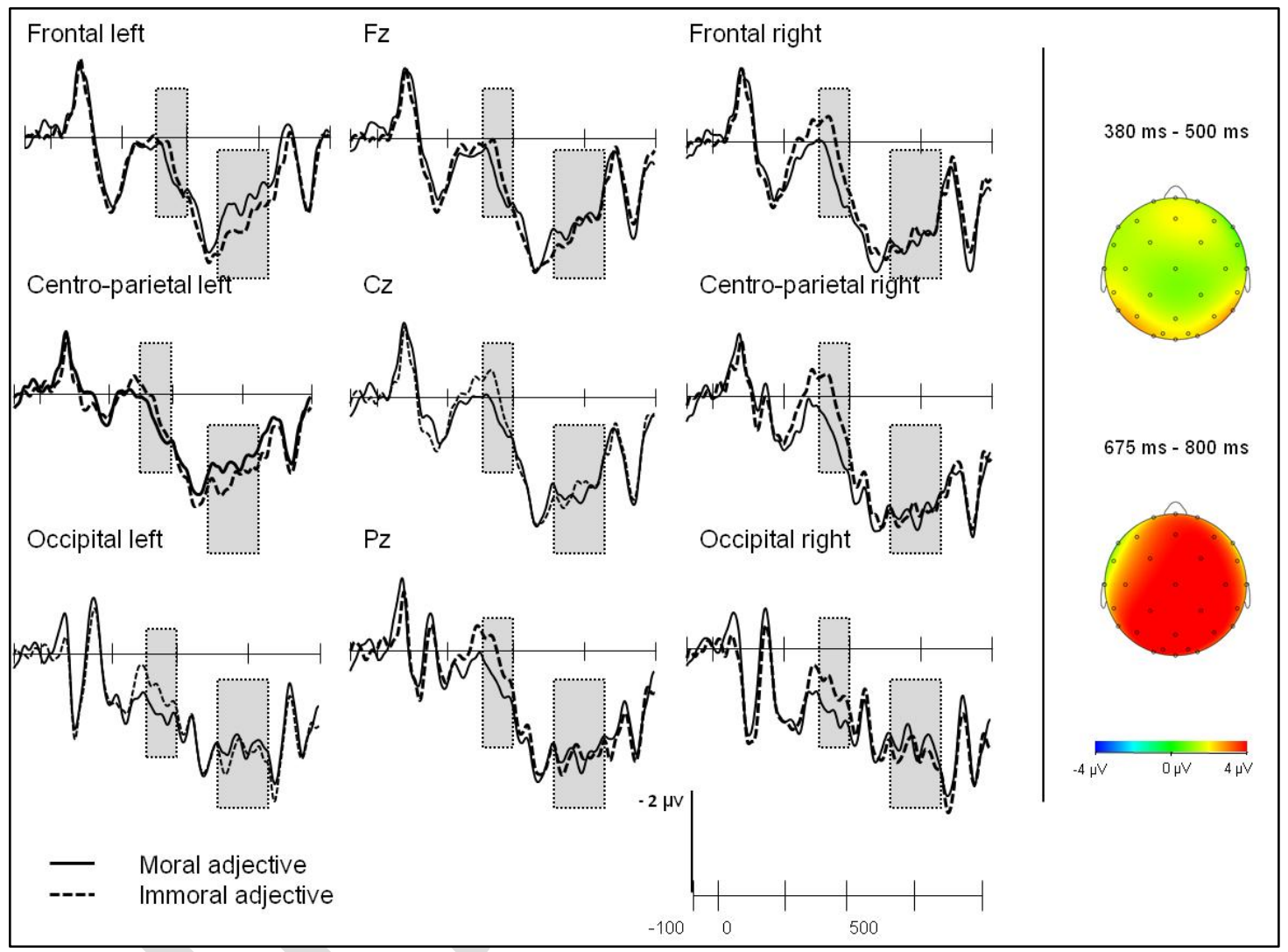

Figure 1. ERPs for the native group. Left panel: Event-related potential results for the critical adjective of the sentence. Time zero indicates the presentation of the adjective. Black lines depict ERPs measured for moral adjectives; dotted lines depict ERPs measured for immoral adjectives. ERPs measured over single channels at midline sites (Fz, Cz, Pz) and averaged channels (for presentation only) at Frontal left (F7, F3, FC5, FC1), Frontal right (F8, F4, FC6, FC2), Centro-parietal left (T3, C3, CP5, CP1), Centroparietal right (T4, C4, CP6, CP2), Occipital left (T5, P3, PO1, O1) and Occipital right (O2, PO2, T6, P4) regions. The grey rectangles represent the time-windows analysed. 
Negativity is plotted up. Right panel: Topographic distributions of the difference between the Moral and Immoral conditions across the $380-500 \mathrm{~ms}$ and $675-800 \mathrm{~ms}$ time-windows.

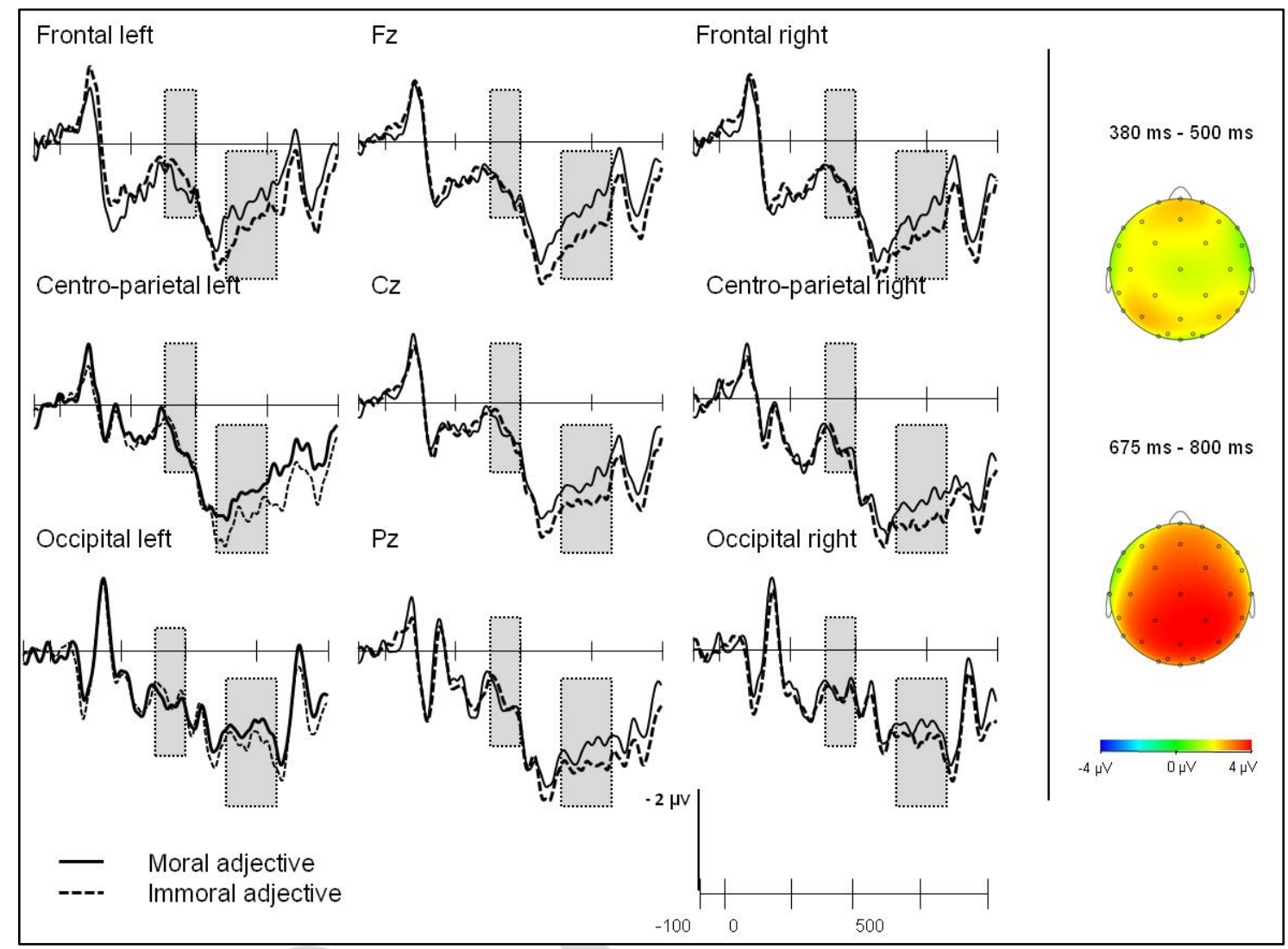

Figure 2. ERPs for the L2 group. Left panel: Event-related potential results for the critical adjective of the sentence. Time zero indicates the presentation of the adjective. Black lines depict ERPs measured for moral adjectives; dotted lines depict ERPs measured for immoral adjectives. ERPs measured over single channels at midline sites (Fz, Cz, Pz) and averaged channels (for presentation only) at Frontal left (F7, F3, FC5, FC1), Frontal right (F8, F4, FC6, FC2), Centro-parietal left (T3, C3, CP5, CP1), Centroparietal right (T4, C4, CP6, CP2), Occipital left (T5, P3, PO1, O1) and Occipital right (O2, PO2, T6, P4) regions. The grey rectangles represent the time-windows analysed. Negativity is plotted up. Right panel: Topographic distributions of the difference 
between the Moral and Immoral conditions across the 380-500 ms and 675-800 ms time-windows.

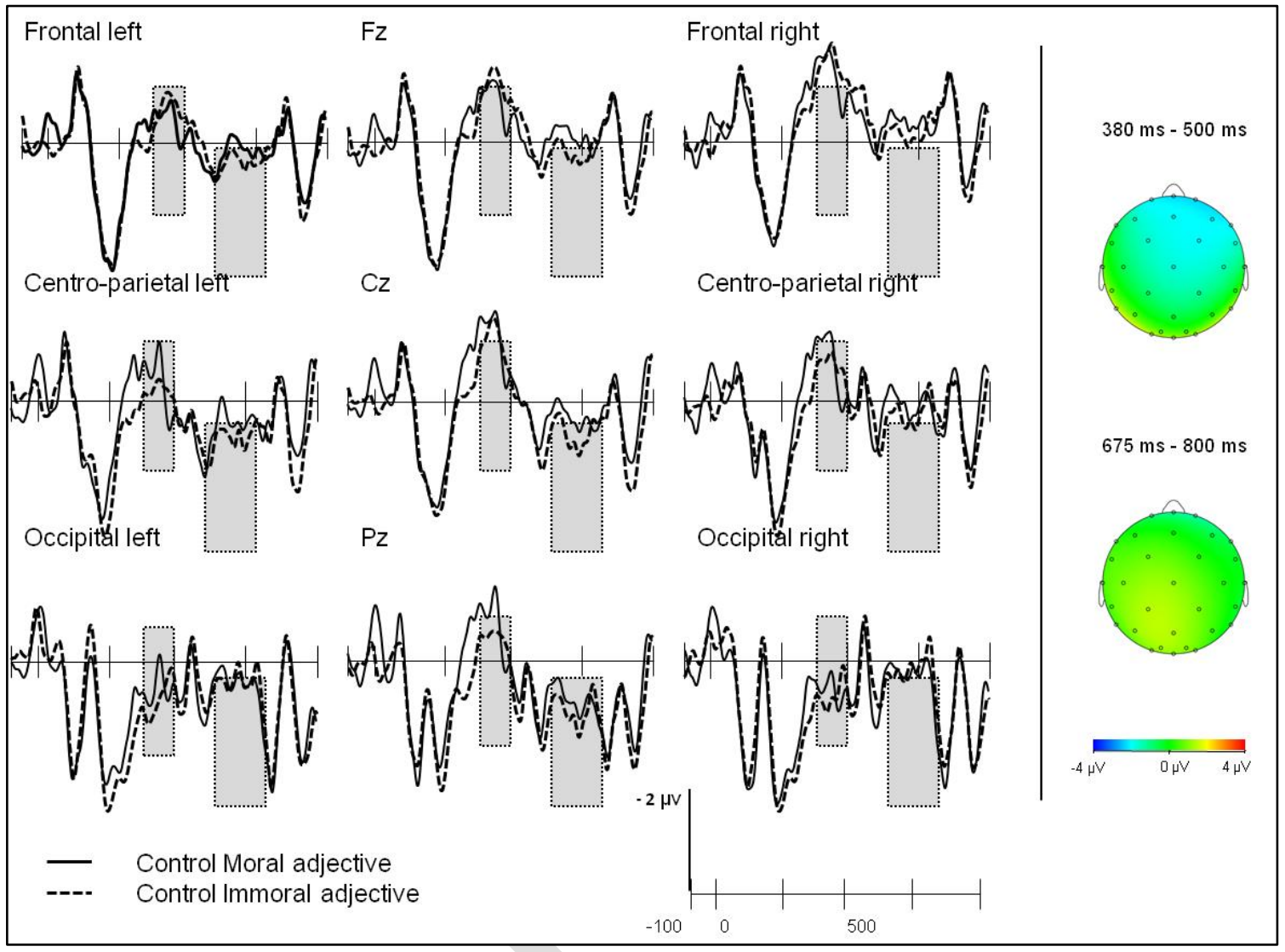

Figure 3. ERPs for the native group. Left panel: Event-related potential results for the control adjective of the sentence. Time zero indicates the presentation of the adjective. Black lines depict ERPs measured for control moral adjectives; dotted lines depict ERPs measured for control immoral adjectives. ERPs measured over single channels at midline sites (Fz, Cz, Pz) and averaged channels (for presentation only) at Frontal left (F7, F3, FC5, FC1), Frontal right (F8, F4, FC6, FC2), Centro-parietal left (T3, C3, CP5, CP1), Centro-parietal right (T4, C4, CP6, CP2), Occipital left (T5, P3, PO1, O1) and Occipital right $(\mathrm{O} 2, \mathrm{PO} 2, \mathrm{~T} 6, \mathrm{P} 4)$ regions. The grey rectangles represent the timewindows analysed. Negativity is plotted up. Right panel: Topographic distributions of 
the difference between the Control Moral and Control Immoral conditions across the 380-500 ms and 675-800 ms time-windows.

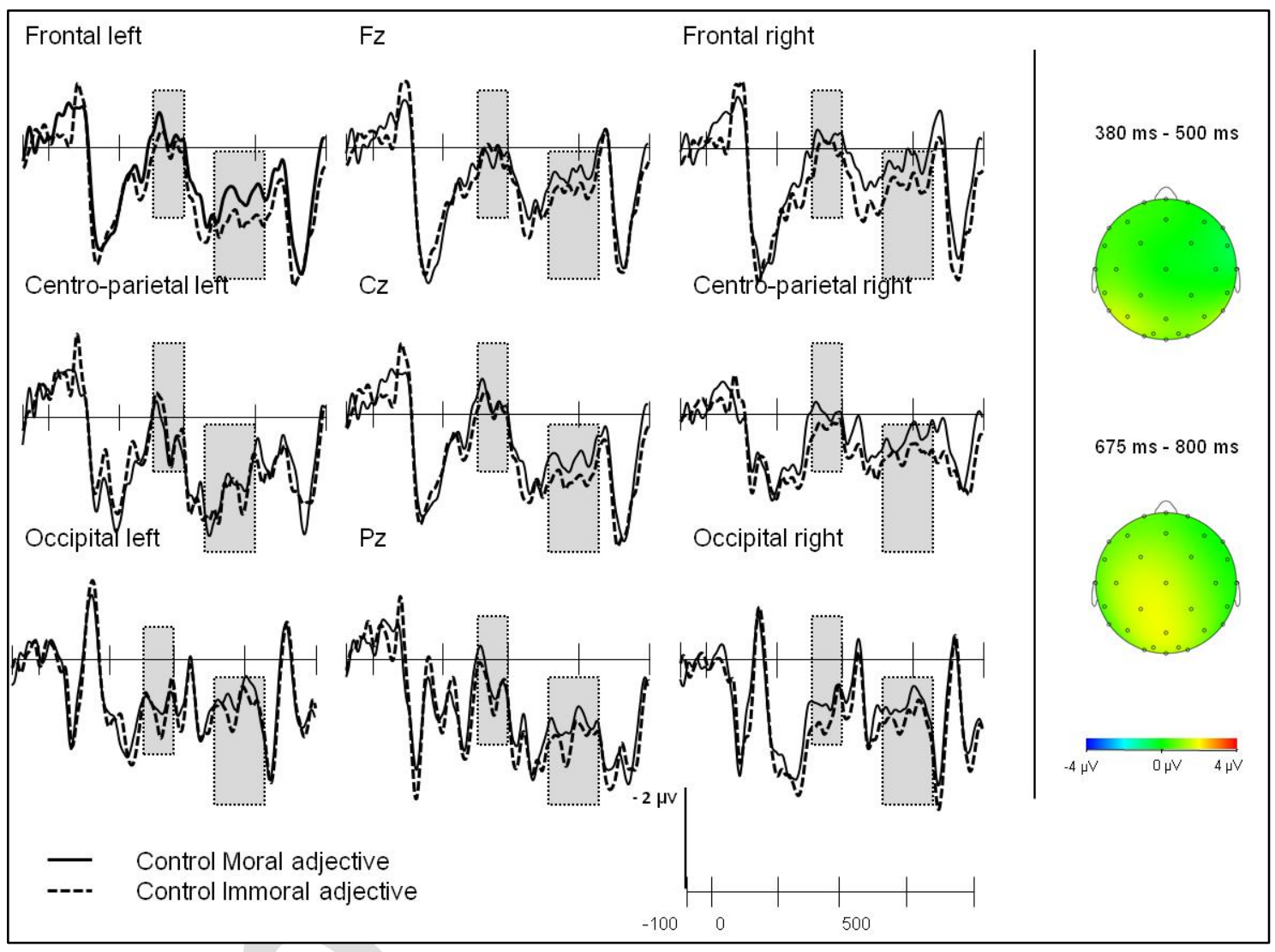

Figure 4. ERPs for the L2 group. Left panel: Event-related potential results for the control adjective of the sentence. Time zero indicates the presentation of the adjective. Black lines depict ERPs measured for control moral adjectives; dotted lines depict ERPs measured for control immoral adjectives. ERPs measured over single channels at midline sites (Fz, Cz, Pz) and averaged channels (for presentation only) at Frontal left (F7, F3, FC5, FC1), Frontal right (F8, F4, FC6, FC2), Centro-parietal left (T3, C3, CP5, CP1), Centro-parietal right (T4, C4, CP6, CP2), Occipital left (T5, P3, PO1, O1) and Occipital right $(\mathrm{O} 2, \mathrm{PO} 2, \mathrm{~T} 6, \mathrm{P} 4)$ regions. The grey rectangles represent the timewindows analysed. Negativity is plotted up. Right panel: Topographic distributions of 
the difference between the Control Moral and Control Immoral conditions across the 380-500 ms and 675-800 ms time-windows.

In sum, the behavioural results showed no differences between native and non-native speakers in their moral judgement. In contrast, the ERP results show that while both groups revealed a larger LPP for immoral statements compared to moral statements, the N400 modulation by morality value was only observed in the L1 group.

\section{Discussion}

The present study examined whether valuation is integrated incrementally during L2 sentence comprehension and whether it affects non-native speakers' online interpretation of the message. We adapted Van Berkum et al.'s (2009) study to Spanish, and presented Spanish native speakers and French-Spanish mid-proficiency late L2 learners with statements that were either consistent with their moral values or not. Importantly, the sentences did not include any semantic violation; the only 'violation' occurred at valuation level (i.e., whether in agreement with one’s moral values or not).

In the L1 group, our results replicated Van Berkum et al.'s in that critical words that clashed with participants' moral values first provoked an N400 followed by a small LPP. In line with these authors, we interpret the N400 effect observed as an indication of difficulty of early sense making. That is, let us argue that the sentence context (e.g., 'Nowadays, paedophilia should be...') primes a particular concept (e.g., here 'paedophilia'), or that the reader builds up expectation based on her values as the sentence context unfolds. If the critical word clashes with the word (or the concept) that is expected, it provokes semantic integration difficulty, reflected by an enhancement of the N400 ERP component (DeLong, Urbach, \& Kutas, 2005; Foucart et al., 2014; Wicha, Moreno, \& Kutas, 2004). Interestingly, similarly as Van Berkum et al., we 
observed the N400 effect at centro-posterior sites, which is the classic distribution of this component. Hence, value-inconsistent statements provoke a similar response (in terms of timing and distribution) as semantic violations and unexpected words.

We consider the LPP an affect-related component indexing that additional processing is required for value-inconsistent statements compared to value-consistent statements, similarly as the additional processing usually observed for emotional stimuli (for a review, see Citron, 2012). Furthermore, the LPP in our study had a centroposterior distribution as that usually observed for emotional stimuli. These results suggest that semantic processes in L1 comprehension are sensitive to valuation and that value-based disagreements influence online sentence comprehension.

French-Spanish L2 speakers showed somehow different results. While their behavioural responses suggested that they valuated the statements equally (im-)moral as L1 speakers, their brain activity revealed a different pattern; in response to valueinconsistent statements, L2 speakers revealed an LPP but no N400 effect. These results suggest that valuation is integrated online (presence of LPP) but that it does not interfere with semantic processing (absence of N400).

The presence of the LPP indicates that the adjective was processed online in relation to its sentential context. Indeed, since the positive and negative connotation of the critical adjectives was mixed for each condition, the LPP cannot reflect participants' sensitivity to the affective valence of the adjective itself as it is the case for single words; the LPP is therefore clearly the evidence of participants' sensitivity to the valence of the adjective in relation to the preceding context. This conclusion is also supported by the absence of LPP in the control condition in which the adjective was presented at the beginning of the sentence and hence could not be processed in relation to the sentence context. This observation suggests that late L2 speakers valuate words 
online in relation to the preceding context. This online processing would not be possible without the integration of both semantic and valuation information. Thus, the present results suggest that semantic and valuation processes interact during sentence processing in L2, however, valuation does not seem to influence sentence interpretation in the same way as in L1, as reflected by the absence of N400 effect. Importantly, the distribution of the LPP was similar in the two groups, and was comparable to that usually observed for emotional stimuli (i.e., at centro-posterior sites). On the other hand, the separate analyses per region confirmed that the N400 component was absent over the whole scalp in L2, suggesting that the difference of pattern between the L2 speakers and the native speakers was more likely due to processing differences than to distributional differences.

One potential explanation to account for the absence of N400 effect is L2 speakers' sensitivity to affect-based stimuli. As put forward by Van Berkum and colleagues, the valence of a concept may be part of its meaning, and thus concepts that mismatch with one's value provoke an N400 modulation equivalent to that observed for semantic anomalies (e.g., I take my coffee with cream and dog). In L2, however, since the emotional reaction is usually reduced (Caldwell-Harris \& Ayçiçeği-Dinn, 2009; Dewaele, 2004; Opitz \& Degner, 2012; Pavlenko, 2005), the valence of the concept might not be as automatically activated from the word as it is in L1. In this case, valuebased inconsistent concepts in L2 should not be considered as semantic anomalies and therefore no N400 effect should emerge. Note, however, that emotional reaction in L2 processing varies with factors such as age of acquisition, proficiency, and exposure (Conrad et al., 2011; Eilola, Havelka, \& Sharma, 2007; Harris, 2004; Sutton, Altarriba, Gianico, \& Basnight-Brown, 2007); hence, if this explanation is true, an N400 effect should be observed for L2 speakers who have reached native-like emotional sensitivity. 
Another possibility for the absence of an N400 effect is non-native speakers' questioned ability to anticipate words during sentence processing. If L2 speakers do not build up lexical (or conceptual) expectation as the sentence context unfolds like native speakers do, any word that fits semantically, whatever consistent or inconsistent with the reader's value, would be easily integrated within the semantic context and would therefore not trigger an N400 effect. This explanation is rather unlikely since, as mentioned in the Method, the French-Spanish participants who took part in the present study also took part in Foucart et al.'s (2014) study which investigated word anticipation in L2. In the later experiment, they displayed an N400 effect when processing words that were unexpected from the sentence context, showing that they anticipated upcoming words online in a similar way as L1 speakers. Hence, it is improbable that the absence of N400 here be due to L2 speakers' ability to anticipate.

Finally, another account for the absence of N400 modulation in the L2 group is timing. This account is speculative because it is based on the hypothesis that the onset of the LPP in the L1 group is earlier than in the L2 group. From the grand averages, it seems clear that the onset of the LPP in the L2 group occurs after $500 \mathrm{~ms}$. On the other hand, the onset in the L1 group is not as clear; we can speculate that the onset of the LPP in L1 occurs within the same time-window as the N400 (380-500 ms) and is therefore indiscernible. This would suggest that valuation is slightly delayed in L2 compared to L1; consequently, the valence of the adjective may not be processed quickly enough to exert an effect on semantic processing. That is, by the time the valence of the adjective is processed, L2 speakers have already integrated the word with no difficulty since it fits semantically in the sentence context. Hence, even if the adjective conflicts with one's moral values and should trigger integration difficulty reflected by a modulation of the $\mathrm{N} 400$, the only visible reaction to value-inconsistent 
statements is the affect-related LPP. This is a speculative but nevertheless possible explanation.

\section{Conclusion}

The present study shows that both semantic and valuation are integrated online during L2 sentence comprehension. However, valuation does not seem to influence the online interpretation of a sentence in the same way as in L1. This suggests that L2 speakers may have difficulties in processing information of different sorts (e.g., semantic and pragmatic) during sentence processing. These difficulties may explain the delay often observed in L2 sentence processing (for reviews, see Frenck-Mestre et al., 2014; Moreno et al., 2008). One way for L2 speakers to initially compensate for their difficulty may be to rely on cues that are linguistically independent and thus more accessible, like pragmatics (Roberts \& Felser, 2011; Roberts et al., 2008) or indexical properties (Foucart et al., 2015), for example. However, highly proficient L2 speakers should eventually process sentences in the same way as native speakers do. Further research involving other types of information is needed to extend our understanding of L2 sentence comprehension. 


\section{Acknowledgements}

This work was supported by grants from the Spanish Government (PSI2011-23033, CONSOLIDER-INGENIO2010 CSD2007-00048, ECO2011-25295, and ECO201009555-E), from the Catalan Government (SGR 2009-1521) and from the 7th Framework Programme (AThEME 613465). Clara Martin is supported by the Basque Foundation for Science (IKERBASQUE) and the BCBL institution. 


\section{References}

Ardal, S., Donald, M. W., Meuter, R., Muldrew, S., \& Luce, M. (1990). Brain responses to semantic incongruity in bilinguals. Brain and Language, 39(2), 187-205. Retrieved from http://www.ncbi.nlm.nih.gov/pubmed/2224493

Cacioppo, J. T., Crites, S. L., Berntson, G. G., \& Coles, M. G. H. (1993). If attitudes affect how stimuli are processed, should they not affect the event-related brain potential? Psychological Science, 4, 108-112.

Caldwell-Harris, C., \& Ayçiçeği-Dinn, A. (2009). Emotion and lying in a non-native language. International Journal of Psychophysiology: Official Journal of the International Organization of Psychophysiology, 71(3), 193-204. doi:10.1016/j.ijpsycho.2008.09.006

Citron, F. M. M. (2012). Neural correlates of written emotion word processing: a review of recent electrophysiological and hemodynamic neuroimaging studies. Brain and Language, 122(3), 211-26. doi:10.1016/j.bandl.2011.12.007

Conrad, M., Recio, G., \& Jacobs, A. M. (2011). The Time Course of Emotion Effects in First and Second Language Processing: A Cross Cultural ERP Study with German-Spanish Bilinguals. Frontiers in Psychology, 2(December), 351. doi:10.3389/fpsyg.2011.00351

Crites, S. L., Cacioppo, J. T., Gardner, W. L., \& Berntson, G. G. (1995). Bioelectrical echoes from evaluative categorization: II. A late positive brain potential that varies as a function of attitude registration rather than attitude report. Journal of Personality and Social Psychology, 68(6), 997-1013. Retrieved from http://www.ncbi.nlm.nih.gov/pubmed/7608861

Cuthbert, B. N., Schupp, H. T., Bradley, M. M., Birbaumer, N., \& Lang, P. J. (2000). Brain potentials in affective picture processing: covariation with autonomic arousal and affective report. Biological Psychology, 52(2), 95-111. Retrieved from http://www.ncbi.nlm.nih.gov/pubmed/10699350

Davis, C. J., \& Perea, M. (2005). BuscaPalabras: a program for deriving orthographic and phonological neighborhood statistics and other psycholinguistic indices in Spanish. Behavior Research Methods, 37(4), 665-71. Retrieved from http://www.ncbi.nlm.nih.gov/pubmed/16629300

DeLong, K. A., Urbach, T. P., \& Kutas, M. (2005). Probabilistic word pre-activation during language comprehension inferred from electrical brain activity. Nature Neuroscience, 8(8), 1117-21. doi:10.1038/nn1504

Dewaele, J. M. (2004). The Emotional Force of Swearwords and Taboo Words in the Speech of Multilinguals. Journal of Multilingual \& Multicultural Development, 25, 204-222. doi:doi:10.1080/01434630408666529.

Eilola, T. M., Havelka, J., \& Sharma, D. (2007). Emotional activation in the first and second language. Cognition \& Emotion, 21, 1064-1076.

Felser, C., Sato, M., \& Bertenshaw, N. (2009). The on-line application of binding Principle A in English as a second language. Bilingualism: Language and Cognition, 12, 485-502. 
Foucart, A., Garcia, X., Ayguasanosa, M., Thierry, G., Martin, C., \& Costa, A. (2015). Does the speaker matter? Online processing of semantic and pragmatic information in L2 speech comprehension. Neuropsychologia, 75, 291-303.

doi:10.1016/j.neuropsychologia.2015.06.027

Foucart, A., Martin, C. D., Moreno, E. M., \& Costa, A. (2014). Can Bilinguals See It Coming? Word Anticipation in L2 Sentence Reading. Journal of Experimental Psychology: Learning , Memory, and Cognition, 1461-9.

Frenck-Mestre, C., Sneed German, E., \& Foucart, A. (2014). Qualitative differences in native and non-native semantic processing as revealed by ERPs. In R. R. Heredia \& J. Altarriba (Eds.), Foundations of bilingual memory. (Springer S.). New York, NY.

Greenhouse, S. W., \& Geisser, S. (1959). On methods in the analysis of profile data. Psychometrika, 24, 95-112.

Hagoort, P., Hald, L., Bastiaansen, M., \& Petersson, K. M. (2004). Integration of word meaning and world knowledge in language comprehension. Science (New York, N.Y.), 304(5669), 438-41. doi:10.1126/science.1095455

Hahne, A. (2001). What's different in second-language processing? Evidence from eventrelated brain potentials. Journal of Psycholinguistic Research, 30(3), 251-66. Retrieved from http://www.ncbi.nlm.nih.gov/pubmed/11523274

Hahne, A., \& Friederici, A. D. (2001). Processing a second language: late learners' comprehension mechanisms as revealed by event-related brain potentials. Bilingualism: Language and Cognition, 4(2), 123-141.

Hajcak, G., MacNamara, A., \& Olvet, D. M. (2010). Event-related potentials, emotion, and emotion regulation: an integrative review. Developmental Neuropsychology, 35(2), 12955. doi:10.1080/87565640903526504

Harris, C. (2004). Bilingual Speakers in the Lab: Psychophysiological Measures of Emotional Reactivity. Journal of Multilingual and Multicultural Development, 25(2-3), 223-247. doi:10.1080/01434630408666530

Kutas, M., \& Hillyard, S. . (1980). Reading senseless sentences: Brain potentials reflect semantic incongruity. Science, 207, 203- 205.

Kutas, M., \& Kluender, R. (1994). What Is Who Violating? A Reconsideration of Linguistic Violations in Light of Event-Related Brain Potentials. In H.-J. Heinze, T. F. Munte, \& G. R. Mangun (Eds.), Cognitive Electrophysiology (pp. 183-210). Boston: Birkhauser.

Martin, C. D., Garcia, X., Breton, A., Thierry, G., \& Costa, A. (n.d.). World Knowledge integration during second language comprehension. Language, Cognition and Neuroscience.

Martin, C. D., Garcia, X., Breton, A., Thierry, G., \& Costa, A. (2014). From literal meaning to veracity in two hundred milliseconds. Frontiers in Human Neuroscience, 8, 40. doi:10.3389/fnhum.2014.00040 
Meuter, R., Donald, M. W., \& Ardal, S. (1987). A comparison of first- and second-language ERPs in bilinguals. Electroencephalography and Clinical Neurophysiology. Supplement, 40, 412-6. Retrieved from http://www.ncbi.nlm.nih.gov/pubmed/3480157

Moreno, E. M., Rodriguez-Fornells, A., \& Laine, M. (2008). Event-Related Potentials (ERPs) in the study of bilingual language processing. Journal of Neurolinguistics, 21, 477-508.

Opitz, B., \& Degner, J. (2012). Emotionality in a second language: it’s a matter of time. Neuropsychologia, 50(8), 1961-7. doi:10.1016/j.neuropsychologia.2012.04.021

Pavlenko, A. (2005). Emotions and multilingualism. New York, NY: Cambridge University Press. doi:doi:10.1017/CBO9780511584305

Psychology Software Tools, I. [E-P. 2. 0]. (2012). E-Prime 2.0. Retrieved from Retrieved from http://www.pstnet.com.

Roberts, L., \& Felser, C. (2011). Plausibility and recovery from garden paths in second language sentence processing. Applied Psycholinguistics, 32(02), 299-331. doi:10.1017/S0142716410000421

Roberts, L., Gullberg, M., \& Indefrey, P. (2008). Online pronoun resolution in L2 discourse, 333-357.

Sutton, T. M., Altarriba, J., Gianico, J. L., \& Basnight-Brown, D. M. (2007). The automatic access of emotion: emotional stroop effects in Spanish- English bilingual speakers. Cognition \& Emotion, 21, 1077-1090.

Tokowicz, N., \& MacWhinney, B. (2005). Implicit and explicit measures of sensitivity to violations in second language grammar: An Event-Related Potential Investigation. Studies in Second Language Acquisition, 27(02), 173-204. doi:10.1017/S0272263105050102

Van Berkum, J. J. A., Holleman, B., Nieuwland, M. S., Otten, M., \& Murre, J. (2009). Right or wrong? The brain's fast response to morally objectionable statements. Psychological Science, 20(9), 1092-9. doi:10.1111/j.1467-9280.2009.02411.x

Van Berkum, J. J. A., van den Brink, D., Tesink, C. M. J. Y., Kos, M., \& Hagoort, P. (2008). The neural integration of speaker and message. Journal of Cognitive Neuroscience, 20(4), 580-91. doi:10.1162/jocn.2008.20054

Van Hell, J. G., \& Tokowicz, N. (2010). Event-related brain potentials and second language learning: syntactic processing in late L2 learners at different L2 proficiency levels. Second Language Research, 26(1), 43-74. doi:10.1177/0267658309337637

Weber-Fox, C. M., \& Neville, H. J. (1996). Maturational Constraints on Functional Specializations for Language Processing: ERP and Behavioral Evidence in Bilingual Speakers. Journal of Cognitive Neuroscience, 8(3), 231-256. doi:10.1162/jocn.1996.8.3.231

Wicha, N. Y. Y., Moreno, E. M., \& Kutas, M. (2004). Anticipating words and their gender: an event-related brain potential study of semantic integration, gender expectancy, and gender agreement in Spanish sentence reading. Journal of Cognitive Neuroscience, 16(7), 127288. doi:10.1162/0898929041920487 


\section{Appendix. Full list of experimental and control sentences in Spanish with English}

(literal) translation. Moral and immoral critical adjectives are underlined.

\section{Experimental sentences}

Pienso que consumir cocaína cada día es peligroso/inofensivo para la salud.

I think that taking cocaine every day is dangerous/safe for your health.

Las personas que tienen sida son delicadas/peligrosas en mi opinión. People who have aids are delicate/dangerous in my opinion.

Que los niños africanos mueran de hambre es catastrófico/beneficioso según mi opinión.

The fact that African children die of starvation is catastrophic/beneficial according to me.

Los homosexuales tendrían que ser aceptados/exterminados en mi opinión.

Homosexuals should be accepted/exterminated in my opinion.

La ablación del clítoris tendría que ser ilegal/universal en mi opinión.

Female circumcision should be illegal/universal in my opinion.

Creo que el tráfico de órganos debería estar prohibido/permitido en nuestra sociedad.

I believe organ traffic should be prohibited/permitted in our society.

Insultar a los padres es inaceptable/aceptable bajo mi punto de vista. Insult one's parents is unacceptable/acceptable in my point of view.

Creo que pegar a los niños es negativo/positivo para su educación. I believe hitting children is negative/positive for their education.

Matar a alguien por dinero es intolerable/comprensible en mi opinión.

Killing someone for Money is intolerable/understandable in my opinion.

Creo que esclavitud debería estar prohibida/permitida en todos los países.

I believe slavery should be prohibited/permitted in all the countries.

Pienso que las sectas deberían estar prohibidas/permitidas en nuestra sociedad.

I think sects should be prohibited/permitted in our society.

Para mí, el divorcio es comprensible/inaceptable en cualquier caso.

For me, divorce is understandable/unacceptable in any case.

Humillar a los obesos es cruel/divertido para mí.

Humiliating obese people is cruel/fun for me. 
Creo que la pena de muerte debería ser abolida/implantada en todos los países. I believe death penalty should be abolished/implanted in all the countries.

Que la religión intervenga en la política es ridículo/necesario en mi opinión.

The fact religion interferes in politics is ridiculous/necessary in my opinion.

Practicar la eutanasia debería estar permitido/prohibido creo.

Euthanizing should be permitted/prohibited I believe.

El aborto después de una violación es comprensible/inadmisible bajo mi punto de vista. Abortion after rape is understandable/impermissible in my point of view.

Para mí, el matrimonio homosexual debería ser aprobado/ilegal en nuestra sociedad. For me, gay marriage should be approved/illegal in our society.

Pienso que la emancipación de la mujer es positiva/negativa para la sociedad. I think woman emancipation is positive/negative for society.

Para mí, el racismo es intolerable/comprensible en nuestra época.

For me, racism is intolerable/understandable nowadays.

Vender droga tendría que estar más penalizado/permitido en mi opinión.

Selling drugs should be more penalised/permitted in my opinion.

Pienso que la agresión sexual es imperdonable/perdonable en la mayoría de casos.

I think sexual assault is unforgivable/forgivable in most cases.

La exterminación de los judíos es horrible/disculpable para mí.

Extermination of the Jews is horrible/excusable according to me.

Para mí, que las mujeres no puedan votar es indignante/comprensible en algunos países. For me, the fact that women cannot vote is outrageous/understandable in some countries.

Conducir después de tomar drogas es peligroso/inofensivo en mi opinión.

Driving after taking drugs is dangerous/safe in my opinion.

Dar alcohol a un bebé es intolerable/tolerable para mí.

Giving alcohol to a baby is intolerable/tolerable according to me.

Que las personas mayores no tengan visitas es nocivo/sano para ellas mi opinión. The fact that elderly people do not have visits is damaging/healthy for them in my opinion.

La confianza entre amigos es primordial/innecesaria en mi opinión.

Trust amongst friends is essential/unnecessary in my opinion.

Dar golpes a un bebé que sigue llorando es imperdonable/disculpable en mi opinión. Hitting a baby who keeps crying is unforgivable/excusable in my opinion. 
Creo que un hombre golpee a su mujer es intolerable/disculpable en nuestros tiempos. I believe that a man may beat his wife is intolerable/excusable nowadays.

Una relación de amistad basada en la mentira es inadmisible/admisible según mis criterios.

A friendship based on lies is impermissible/permissible according to my way of thinking.

Cometer un acto cruel contra un ser indefenso es lamentable/divertido en mi opinión. To commit a cruel action against a defenceless is pathetic/fun in my opinion.

Ser deshonesto en el trabajo es una actitud reprobable/válida según mi criterio. Being dishonest at work is a reprehensible/valid behaviour in my way of thinking.

Obligar a prostituirse a una adolescente sin recursos es inmoral/honorable en mi opinión.

Forcing a teenager without resources to practice prostitution is immoral/honourable in my opinion.

Bombardear a los países enemigos es una política muy agresiva/eficiente en mi opinión. Bombarding enemy countries is a very aggressive/efficient policy in my opinion.

El robo de identidad es un acto inaceptable/respetable en mi opinión.

Identity thief is an unacceptable/respectable act in my opinion.

Que los pobres no reciban tratamiento médico caro es injusto/lógico según mi opinión. The fact that poor people do not receive expensive medical treatment is unfair/logic according to me.

Que los políticos puedan cometer cualquier delito es inmoral/normal según mis criterios.

The fact that politicians may commit any crime is immoral/normal in my way of thinking.

Pienso que la discriminación salarial de la mujer es injusta/justa en nuestra sociedad. I think wage discrimination for women is unfair/fair in our society.

El nazismo es una ideología peligrosa/interesante en mi opinión.

Nazism is a dangerous/interesting ideology in my opinion.

Lapidar a una mujer infiel es inmoral/justo para mí.

Stoning an unfaithful woman is immoral/fair according to me.

Golpear en la cara a un padre es inaceptable/aceptable bajo mi punto de vista.

Hitting his father in the face is inacceptable/acceptable in my point of view.

Hacer sufrir a los animales es cruel/divertido en mi opinión.

Making suffer animals is cruel/fun in my opinion. 
En una situación desperrada e insoportable, la eutanasia es comprensible/inadmisible en mi opinión.

In a hopeless and unbearable situation, euthanasia is understandable/impermissible in my opinion.

Abandonar a los perros antes las vacaciones es cruel/disculpable en mi opinión. Abandoning dogs before going on holidays is cruel/excusable in my opinion.

Abusar de la cortesía de alguien es reprobable/comprensible según mis criterios. Taking advantage of someone's courtesy is reprehensible/understandable in my way of thinking.

Utilizar su influencia para ser rico debería ser condenable/defendible en los tribunales. Using one's influence to become rich is punishable/defensible in court.

No ayudar a una persona en peligro es condenable/admisible creo.

Not helping someone who is in danger is punishable/admissible I believe.

Comer animales en peligro de extinción es una tradición inadmisible/honorable en mi opinión.

Eating animals in danger of extinction is an inadmissible/honourable tradition in my opinion.

Vender a tus hijos tendría que ser ilegal/legal bajo mi punto de vista.

Selling one's own children should be illegal/legal in my point of view.

Que un hombre sea infiel a su mujer es lamentable/beneficioso para la pareja.

The fact that a man may be unfaithful to his wife is lamentable/beneficial for the couple.

Que los hombres destruyan la selva amazónica es intolerable/aceptable para nuestra sociedad.

The fact that men destroy the Amazonian forest is intolerable/acceptable for our society.

Robar a los turistas es inaceptable/aceptable cuando visitan la ciudad.

Stealing tourists is unacceptable/acceptable when they are visiting a city.

El incesto tendría que ser prohibido/tolerado en todas las culturas.

Incest should be prohibited/tolerated in all the cultures.

El genocidio es un acto indignante/heroico que ocurre en todo el mundo.

Genocide is an outrageous/heroic act that happens in the entire world.

Discriminar a los obesos es inaceptable/aceptable en nuestra sociedad.

Discriminating obese people is unacceptable/acceptable in our society.

Hacer sufrir a los animales es injusto/necesario en los laboratorios.

Making suffer animals is unfair/necessary in laboratories.

Discriminar a las personas discapacitadas es injusto/normal en nuestra sociedad.

Discriminating disabled people is unfair/normal in our society. 
En nuestra época, la pedofilia debería ser prohibida/tolerada en todo el mundo. Nowadays, pedophilia should be prohibited/tolerated in the entire world.

En nuestra época, utilizar preservativos debería estar recomendado/prohibido en todo el mundo.

Nowadays, using condoms should be recommended/prohibited in the entire world.

La guerra es una solución horrible/necesaria para arreglar los conflictos.

War is a horrible/necessary solution to solve conflicts.

Tener hijos fuera del matrimonio es normal/inimaginable para las nuevas generaciones. Having children out of marriage is normal/unimaginable for new generations.

En nuestros tiempos, el sexo prematrimonial es aceptable/intolerable en nuestra sociedad.

Nowadays, sex before marriage is acceptable/intolerable in our society.

Las personas negras han sido iguales/inferiores a los blancos desde siempre.

Black people have been equal/inferior to white people since always.

Actualmente la tortura debería ser abolida/utilizada por la justicia.

At present, torture should be abolished/used by justice.

Que un hombre golpee a su mujer es malo/necesario en una pareja.

The fact that a man beats his wife is bad/necessary in a couple.

Que una mujer beba alcohol cuando está embarazada es peligroso/inofensivo para el bebé.

The fact that a woman drinks alcohol when pregnant is dangerous/inoffensive for the baby.

Tanta miseria en el mundo es indignante/beneficiosa para la humanidad. So much misery in the world is outrageous/beneficial for humanity.

Que los niños crezcan en guerra es catastrófico/beneficioso para su desarrollo.

The fact that children grow in war is catastrophic/beneficial for their development.

Mentir a tu mejor amigo es imperdonable/admisible en cualquier caso.

Lying to your best friend is unforgivable/admissible in any case.

El examen prenatal de discapacidad tendría que ser/estar obligatorio/prohibido en todos países.

The prenatal test for disability should be compulsory/prohibited in all the countries.

Que haya gente que duerma en la calle es inadmisible/admisible en nuestra sociedad.

The fact that people sleep in the street is inadmissible/admissible in our society.

Tener sexo con niños tendría que ser sancionado/tolerado en todos los países. Having sex with children should be penalised/tolerated in all the countries. 
Acostarse con la mujer de tu mejor amigo está mal/justificado en muchas circunstancias.

Sleeping with you best friend's wife is wrong/justified in many circumstances.

Hacer trampas en el juego es deshonesto/honesto por parte de quién lo hace.

Cheating when playing is dishonest/honest from whoever is doing it.

Que un niño sea maltratado en la escuela es negativo/positivo para su maduración. The fact that a child may be bullied at school is negative/positive for his development.

La explotación infantil tendría que ser ilegal/legal en todos los países.

Child exploitation should be illegal/legal in all the countries.

Robar las ideas intelectuales de otros es inmoral/honorable en muchos trabajos.

Stealing other's intellectual ideas is immoral/honourable in many works.

Espiar el teléfono de tu pareja es insano/sano para el matrimonio.

Checking the phone of one's partner is unhealthy/healthy for the marriage.

El uso de bombas nucleares tendría que ser evitado/sistemático en un conflicto.

Using nuclear bombs should be avoided/systematic in a conflict.

\section{Control sentences}

Es peligroso/inofensivo para la salud consumir cocaína cada día.

It is dangerous/safe for your health to take cocaine every day.

Parecen delicadas/peligrosas las personas que tienen sida.

They look delicate/dangerous those people who have aids.

Es catastrófico/beneficioso que los niños africanos mueran de hambre.

It is catastrophic/beneficial that African children die of starvation.

Tendrían que ser aceptados/exterminados todos los homosexuales.

They should be accepted/exterminated all the homosexuals.

Tendría que ser ilegal/universal la ablación del clítoris.

It should be illegal/universal female circumcision.

Debería estar prohibido/permitido el tráfico de órganos.

It should be prohibited/permitted the organ traffic.

Es inaceptable/aceptable insultar a los padres.

It is unacceptable/acceptable to insult one's parents.

Es negativo/positivo para su educación pegar a los niños.

It is negative/positive for their education to hit children. 
Es intolerable/comprensible matar a alguien por dinero.

It is intolerable/understandable to kill someone for Money.

Debería estar prohibida/permitida la esclavitud.

It should be prohibited/permitted slavery.

Deberían estar prohibidas/permitidas las sectas en nuestra sociedad.

They should be prohibited/permitted the sects in our society.

Veo comprensible/inaceptable el divorcio.

I find it understandable/unacceptable divorce.

Es cruel/divertido humillar a los obesos.

It is cruel/fun to humiliate obese people.

Debería ser abolida/implantada la pena de muerte.

It should be abolished/implanted death penalty.

Es ridículo/necesario que la religión intervenga en la política.

It is ridiculous/necessary that religion interferes in politics.

Debería estar permitido/prohibido practicar la eutanasia.

It should be permitted/prohibited to euthanize.

Considero comprensible/inadmisible el aborto después de una violación.

I consider understandable/impermissible abortion after rape.

Debería ser aprobado/ilegal el matrimonio homosexual.

It should be approved/illegal gay marriage.

Considero positiva/negativa para la sociedad la emancipación de la mujer.

I consider positive/negative for society woman emancipation.

Considero intolerable/comprensible el racismo.

I consider intolerable/understandable racism.

Tendría que estar más penalizado/permitido vender droga.

It should be more penalised/permitted to sell drugs.

Veo imperdonable/perdonable la agresión sexual.

I find it unforgivable/forgivable sexual assault.

Es horrible/disculpable la exterminación de los judíos.

It is horrible/excusable the extermination of the Jews.

Es indignante/comprensible que las mujeres no puedan votar en algunos países.

It is outrageous/understandable that women cannot vote in some countries.

Es peligroso/inofensivo conducir después de tomar drogas.

It is dangerous/safe to drive after taking drugs. 
Parece intolerable/tolerable dar alcohol a un bebé.

It looks intolerable/tolerable to give alcohol to a baby.

Es nocivo/sano que las personas mayores no tengan visitas.

It is damaging/healthy that elderly people do not have visits.

Considero primordial/innecesaria la confianza entre amigos.

I consider essential/unnecessary trust amongst friends.

Veo imperdonable/disculpable en mi opinión dar golpes a un bebé que sigue llorando. I find it unforgivable/excusable to hit a baby who keeps crying.

Es intolerable/disculpable que un hombre golpee a su mujer. It is intolerable/excusable that a man beats his wife.

Es inadmisible/admisible una relación de amistad basada en la mentira. It is impermissible/permissible a friendship based on lies.

Es lamentable/divertido cometer un acto cruel contra un ser indefenso. It is pathetic/fun to commit a cruel action against a defenceless.

Veo una actitud reprobable/válida ser deshonesto en el trabajo. I find it a reprehensible/valid behaviour to be dishonest at work.

Es inmoral/honorable obligar a prostituirse a una adolescente sin recursos.

It is immoral/honourable to force a teenager without resources to practice prostitution.

Es una política muy agresiva/eficiente bombardear a los países enemigos.

It is a very aggressive/efficient policy to bombard enemy countries

Es un acto inaceptable/respetable el robo de identidad.

It is an unacceptable/respectable act identity thief.

Es injusto/lógico que los pobres no reciban tratamiento médico caro.

It is unfair/logic that poor people receive expensive medical treatment.

Es inmoral/normal que los políticos puedan cometer cualquier delito.

It is immoral/normal that politicians may commit any crime.

Considero injusta/justa la discriminación salarial de la mujer en nuestra sociedad.

I find it unfair/fair wage discrimination for women in our society.

Parece una ideología peligrosa/interesante el nazismo.

I looks like a dangerous/interesting ideology nazism.

Es inmoral/justo lapidar a una mujer infiel.

It is immoral/fair to stone an unfaithful woman.

Es inaceptable/aceptable golpear en la cara a un padre. 
It is inacceptable/acceptable to hit his father in the face.

Es cruel/divertido hacer sufrir a los animales.

It is cruel/fun to make suffer animals.

Es comprensible/inadmisible la eutanasia en una situación desperrada e insoportable. It is understandable/impermissible euthanasia in a hopeless and unbearable situation.

Es cruel/disculpable abandonar a los perros antes las vacaciones.

It is cruel/excusable to abandon dogs before going on holidays.

Es reprobable/comprensible abusar de la cortesía de alguien.

It is reprehensible/understandable to take advantage of someone's courtesy.

Debería ser condenable/defendible en los tribunales utilizar su influencia para ser rico. It is punishable/defensible in court to use one's influence to become rich.

Veo condenable/admisible no ayudar a una persona en peligro.

I find it punishable/admissible not to help someone who is in danger.

Es una tradición inadmisible/honorable comer animales en peligro de extinción.

It is an inadmissible/honourable tradition to eat animals in danger of extinction.

Tendría que ser ilegal/legal vender a tus hijos.

It should be illegal/legal to sell one's own children.

Es lamentable/beneficioso para la pareja que un hombre sea infiel a su mujer.

It is lamentable/beneficial for the couple that a man may be unfaithful to his wife.

Es intolerable/aceptable que los hombres destruyan la selva amazónica.

It is intolerable/acceptable that men destroy the Amazonian forest.

Es inaceptable/aceptable robar a los turistas.

It is unacceptable/acceptable to steal tourists.

Tendría que ser prohibido/tolerado el incesto.

It should be prohibited/tolerated incest.

El indignante/heroico acto del genocidio ocurre en todo el mundo.

The outrageous/heroic act of genocide happens in the entire world.

Es inaceptable/aceptable discriminar a los obesos.

It is unacceptable/acceptable to discriminate obese people.

Es injusto/necesario hacer sufrir a los animales en los laboratorios.

It is unfair/necessary to make suffer animals in laboratories.

Es injusto/normal discriminar a las personas discapacitadas.

It is unfair/normal discriminate disabled people. 
Debería ser prohibida/tolerada la pedofilia.

It should be prohibited/tolerated pedophilia.

Debería estar recomendado/prohibido utilizar preservativos.

It should be recommended/prohibited to use condoms.

Es horrible/necesario utilizar la guerra para arreglar los conflictos.

It is horrible/necessary to use war to solve conflicts.

Es normal/inimaginable tener hijos fuera del matrimonio.

It is normal/unimaginable having children out of marriage.

Es aceptable/intolerable el sexo prematrimonial.

It is acceptable/intolerable sex before marriage.

Son iguales/inferiores las personas negras respeto a los blancos.

They are equal/inferior black people compare to white people.

Debería ser abolida/utilizada la tortura en todos los casos.

It should be abolished/used torture in any case.

Es malo/necesario que un hombre golpee a su mujer.

It is bad/necessary that a man beats his wife.

Es peligroso/inofensivo para el bebé que una mujer beba alcohol cuando está embarazada.

It is dangerous/inoffensive for the baby that a woman drinks alcohol when pregnant.

Es indignante/beneficiosa tanta miseria en el mundo.

It is outrageous/beneficial so much misery in the world.

Es catastrófico/beneficioso para su desarrollo que los niños crezcan en guerra.

It is catastrophic/beneficial for his development that children grow in war.

Es imperdonable/admisible mentir a tu mejor amigo.

It is unforgivable/admissible lying to your best friend.

Tendría que ser/estar obligatorio/prohibido el examen prenatal de discapacidad.

It should be compulsory/prohibited the prenatal test for disability.

Es inadmisible/admisible que haya gente que duerma en la calle.

It is inadmissible/admissible that people sleep in the street.

Tendría que ser sancionado/tolerado tener sexo con niños.

It should be penalised/tolerated to have sex with children.

Está mal/justificado acostarse con la mujer de tu mejor amigo.

It is wrong/justified to sleep with you best friend's wife.

Es deshonesto/honesto hacer trampas en el juego. 
It is dishonest/honest cheating when playing.

Es negativo/positivo para su maduración que un niño sea maltratado en la escuela. It is negative/positive for his development that a child may be bullied at school.

Tendría que ser ilegal/legal la explotación infantil.

It should be illegal/legal child exploitation.

Es inmoral/honorable robar las ideas intelectuales de otros.

It is immoral/honourable to steal other's intellectual ideas.

Es insano/sano espiar el teléfono de tu pareja.

It is unhealthy/healthy to check the phone of one's partner.

Tendría que ser evitado/sistemático el uso de bombas nucleares.

It should be avoided/systematic to use nuclear bombs.

\footnotetext{
${ }^{1}$ Preliminarily, an omnibus ANOVA was conducted with Groups (L1 vs. L2) as a between participant factor and repeated measures for Morality (Moral vs. Immoral statement) and Regions (Frontal, Centroparietal and Occipital) divided as midline ( $F z, C z, P z, O z)$, frontal sites (left: F7, F3, FC5, FC1, right: F8, F4, FC6, FC2), centro-parietal sites (left: T3, C3, CP5, CP1, right: T4, C4, CP6, CP2) and occipital sites (left: T5, P3, PO1, O1, right; T6, P4, PO2, O2). Results were fairly similar; i.e., in the N400 (380-500 ms) timewindow the main effect of Morality was significant $(F(1,46)=4.69, p<.05)$ and interacted with Group $(F$ $(1,46)=5.42, p<.05)$ but not with Region $(F(6,276)=0.50, p<1)$, revealing a significant effect of Morality in the native speakers group $(p<.01)$ but not in the L2 speakers group $(p=1)$. In the LPP (675$800 \mathrm{~ms})$ time-window, the main effect of Morality $(F(1,46)=5.28, p<.05)$ was significant did not interact with Group $(F(1,46)=2.79, p=.10)$ nor with Region $(F(6,276)=0.60, p=.73)$. No significant effect of Morality was found in the Control condition in any of the time-windows.

${ }^{2}$ We also conducted analyses on statements with which participants agreed (sum of 'I totally agree' and 'I agree') or disagreed (sum of 'I totally disagree' and 'I disagree’); the effects were similar.
} 